\title{
TITLE:
}

\section{An Energy Limit of Hot Electrons in a Bumpy Torus(Abstract_要旨)}

$\operatorname{AUTHOR}(S)$ :

Yuyama, Tetsumori

CITATION:

Yuyama, Tetsumori. An Energy Limit of Hot Electrons in a Bumpy Torus. 京都大学, 2000, 博士(理学)

ISSUE DATE:

2000-11-24

URL:

http://hdl.handle.net/2433/151679

RIGHT: 


\section{【627】}

氏 名湯出哲守

学位(専攻分野) 博士 (理 学)

学位記番号論理博第 1388 号

学位授与の日付平成 12 年 11 月 24 日

学位授与の要件学位 規則第 4 条第 2 項 該 当

学位論文題目 An Energy Limit of Hot Electrons in a Bumpy Torus

(バンピートーラスにおける高温電子のエネルギー限界)

論文調査委員教授曄道恭教授吉川研一教授簯崎努

\section{論文 内容の要旨}

ミラー比が 2 程度の単純ミラーを多数連結して環状に並ベ，プラズマの磁気閉じ込めを目指すトーラスをバンピートーラ スと呼んでいる。バンピートーラスで電子サイクロトロン共鳴加熱を利用してプラズマを生成すると，プラズマ電子は，電 子のプラズマ周波数が加熱用マイクロ波源の周波数にほぼ等しくなるような密度の比較的温度の低い（数 $100 \mathrm{eV} ）$ 成分と,

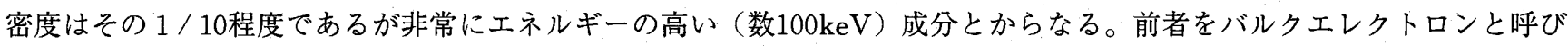
後者をホットエレクトロンと呼んでいる。

周波数が $28 \mathrm{GHz}$ で, 出力が $40 \mathrm{~kW}$ のマイクロ波源を電子サイクロトロン加熱源として用いている名古屋バンピートーラ ス（NBT）で生成されたプラズマ中のホットエレクトロンからの硬エックス線放射について，著者らが行った一連の実験 データをもとに, エックス線のスペクトル解析を行った結果, 数 $\mathrm{MeV} に も$ 達するフォトンが観測されている事実を見出し た。本論文は，この様な高エネルギー電子の生成機構及びエネルギー限界の機構解明を試みたものである。

これまで, ミラー磁場中のホットエレクトロンの生成機構としては非一様磁界中に局所的に出来る電子サイクロトロン共 鳴層近傍の電界の強い領域を電子が通過する際に統計的に加熱されると言ういわゆる統計加熱で説明されてきたが, 相対論

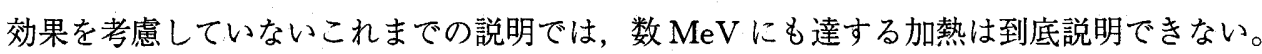

著者は, 電子サイクロトロン周波数の相対論効果によるダウンシフトに着自し, 異常波の電子サイクロトロン高調波共鳴 吸収が重要な役割を果たしていると考え，相対論効果を取入れた分散式を用いて波の減衰率を計算し，電子温度が数 $100 \mathrm{keV} に も な る と ，$ 極めて高次の電子サイクロトロン高調波共鳴で有意の吸収が認められることを見出した。

一方で，バンピートーラスの磁場配位における相対論的エネルギーの電子の閉じ込めは，個別粒子の運動方稈式を解き， 粒子軌道を追跡することで評価できると考え, 色々な初期条件のもとで運動方程式の数値解を求めて軌道を追跡し，トーラ ス容器壁に衝突しない粒子の速度空間における境界を求めた。先に求めた有意の電子サイクロトロン高次高調波共鳴吸収の 認められる領域を速度空間に投影し，著者らの実験で得られた $4 \mathrm{MeV}$ のエネルギー限界の 3 者が交差する点から第10次高 調波共鳴までが電子の加熱に寄与していると結論した。

ついで, 電子のエネルギー損失の主要なものはクーロンドラッグと放射損失であるとし, エネルギーゲインは第10次の電 子サイクロトロン高調波共鳴吸収までであるとしてパワーバランスから，入射マイクロ波電力の 1 割弱の電力がホットエレ クトロンに吸収されていると結論した。

入射マイクロ波電力を変えると, 電子の限界エネルギーも変化する。上述の方法で, 入射マイクロ波電力に対する限界エ ネルギーから寄与し得る高調波次数を求めたものと, ホットエレクトロンへの電力吸収率が変わらないとして，パワーバラ ンスから求めた高調波次数とを比較し，入射マイクロ波電力に対する両者の振舞が定性的に一致することを示した。

以上の考察から，電子のサイクロトロン周波数の相対論効果によるダウンシフトによって，ミラー比が 2 強のバンピート ーラスのセル内で, 電子サイクロトロン高次高調波共鳴吸収が加熱に寄与し得ることを初めて明確に示し, 磁気閉じ込めの 限界エネルギー以下で電子加熱に寄与する最大高調波次数が加熱エネルギーの上限に重要な役割を果たしていると結論して 
いる。

\section{論 文審査 の 結 果 の 要 旨}

申請論文は名古屋バンピートーラスで電子サイクロトロン共鳴加熱を利用してプラズマを生成した際の数 $\mathrm{MeV} に$ 達する ホットエレクトロンの加熱機構とエネルギー限界の機構解明を試みたものである。

バンピートーラスの各セルのミラー比は 2 強であり, 加熱用マイクロ波源の周波数が固定されている場合, 電子サイクロ トロン基本共鳴および第 2 高調波共鳴における加熱を考えるのが一般的であるが，申請者は電子サイクロトロン周波数の相 対論効果によるダウンシフトを考慮に入れることが極めて麓要であるとの発想にもとづき，相対論的分散式を用いて異常波 の電子サイクロトロン高次高調波共鳴吸収を計算し，パンピートーラス内の空間的磁場怖度分布を考慮に入れると，極めて 高次の高調波共鳴まで有意の吸収が期待できることを見出した。

一方，ホットエレクトロンについては平均自由行程が各セルの幾何学的寸法に較べはるかに長いことから単一粒子の運動 方程式を解いてトーラス容器壁に衝突しない粒子のみが閉じ込められるとして，色々な初期条件で計算し，磁場配位から決 まる閉じ込めエネルギーの限界を求めた。

高次高調波共鳴で有意の吸収が起こり得る速度空間上の領域を各高調波毎にプロットし，そこに磁気閉じ込めのエネルギ 一限界を重ね，実験で観測された電子の最大エネルギーを与え，3者の交点から申請者の実験の場合第10次電子サイクロト ロン高調波共鳴までが電子の加熱に寄与していることを示した。次いで，電子のエネルギーゲインは第16次の電子サイクロ トロン高調波共鳴吸収までであるとし，エネルギー損失はクーロンドラッグと放射損失が主要であるとして，ディーティル ドバランスから入射マイクロ波電力の 1 割弱の電力がホットエレクトロンに吸収されていることを示した。この値は閉じ込 め時間の短い高密度低温度のバルク電子の存在を考慮すると妥当なものと評価できる。

以上の解析結果に基づき，エネルギーが数 $\mathrm{MeV} に$ 達するホットエレクトロンの加熱機構として相対論的電子サイクロト ロン高次高調波共鳴が重要な役割を果たしていることを初めて示した。

重水素と三重水素の核融合反応による制御核融合出力が実証された現在，次ぎの課題としてクリーンエネルギー源として 重水素とヘリウム III 核融合反応を目指すいわゆるアドバンスドフュージョンが話題に上りつつある。アドバンスピフユー ジョンではョラズマ温度が $100 \mathrm{KeV}$ 以上のプラズマを生成保持する必要がある。数 $\mathrm{MeV}$ に達する電子の加熱機構の解明は 今後の研究の進展に重要な寄与をなすものと期待される。

申請論文は相対論的高エネルギー電子の電子サイクロトロン高次高調波共鳴による加熱機構を初めて明確に示したもので あり, 学位論文として価値あるものと認める。また, 関連学問分野について試問した結果, 申請者は大学院博士課程終了者 と同等以上の学識を有することを確認した。

以上，平成12年 8 月 31 日論文内容とそれに関連した口頭試問を行った結果合格と認めた。 